RAFAŁ WŁODARCZYK

Uniwersytet Wroctawski

\title{
OKRUCIEŃSTWO, PRZEMOC I WYCHOWANIE WEDŁUG MICHELA DE MONTAIGNE'A. SZKIC Z DEONTOLOGII PEDAGOGICZNEJ
}

\begin{abstract}
Włodarczyk Rafał, Okrucieństwo, przemoc i wychowanie wedtug Michela de Montaigne'a. Szkic $z$ deontologii pedagogicznej [Cruelty, Violence, and Education by Michel de Montaigne. An Essay on Deontology in Education]. Studia Edukacyjne nr 43, 2017, Poznań 2017, pp. 295-314. Adam Mickiewicz University Press. ISSN 1233-6688. DOI: 10.14746/se.2017.43.18

The aim of this paper is to analyze the phenomenon of cruelty according to deontology in education. The cruelty represents a significant threat to the pedagogical relationship for two reasons. Firstly, as one of the forms of aggression. Secondly, it occurs mostly in a hidden or covert form. The author refers to the concepts of cruelty put forth by Michel de Montaigne and Judith N. Shklar. Indicating indicates the difference between cruelty and violence, he points out the measures to prevent the emergence of atrocities in education and everyday life.
\end{abstract}

Key words: cruelty, aggression, violence, education, deontology in education

Przemoc jest ostentacyjna manifestacją władzy

Hannah Arendt

Bystrzy jesteśmy tylko w znęcaniu się nad soba

Michel de Montaigne

Podejmując zagadnienie okrucieństwa na gruncie deontologii pedagogicznej, badań zorientowanych na rozpoznanie powinności i obowiązków moralnych pedagogów, przyjmujemy za rozstrzygnięty problem oceny agresji. Dostępna wiedza na temat występowania agresji w praktyce edukacyjnej pozwala bowiem twierdzić, że jej obecność w procesie wychowania 
daje się co prawda uzasadnić, jednak nie daje się z punktu widzenia pedagogiki moralnie usprawiedliwić1. Niemniej należy mieć na uwadze fakt, że deontologia pedagogiczna nadal napotyka nierozwiązane problemy teoretyczne, podejmując się analizy jej fenomenu. Spory definicyjne, które znajdziemy w literaturze przedmiotu, wynikające głównie $\mathrm{z}$ trudności w wytyczeniu zakresu zjawisk, sprawiają, że terminy agresja i przemoc bywają stosowane zamiennie. Nieostrość znaczeniowa dotyczy zwłaszcza szerokich ujęć, takich jak na przykład przyjęta przez WHO definicja przemocy wobec dziecka, zgodnie z którą jest to „każde zamierzone i niezamierzone działanie osoby dorosłej, społeczeństwa lub państwa, które ujemnie wpływa na zdrowie, rozwój fizyczny lub psychiczny dziecka" 2 . W takim podejściu próby wyodrębnienia aktu przemocy w układzie reakcji czy odróżnienia go od innych form agresji - szerokiej gamy ludzkich działań, które charakteryzują się atakowaniem bądź wrogością ${ }^{3}$ - okrucieństwa, zaniedbania, niszczenia przedmiotów, kontroli, odstraszania, ignorowania itp. z góry skazane są na niepowodzenie, co nie znaczy, że takie próby nie są dla teorii pedagogicznej pożyteczne. Założenie, którego rozwinięcie stanowi niniejszy artykuł, określa, że istnieje jakościowa różnica między okrucieństwem a wąsko rozumianą przemocą - wykorzystującym przewagę użyciem siły fizycznej lub psychicznej przez sprawcę czy sprawców w celu zmuszenia ofiary do zmiany działań lub postaw, podporządkowania się cudzej woli, pozbawienia życia.

Okrucieństwo będące jedną z inkarnacji agresji - zatem zjawiskiem, które $\mathrm{w}$ świetle deontologii i jej zapatrywań na dobro osób pozostających w relacji pedagogicznej należy wyłączyć z praktyki edukacyjnej - wydaje się łatwe do wskazania, o ile występuje wraz z przemocą czy prześladowaniem, przez co bywa z nimi utożsamiane bądź mylone. O wiele trudniej dostrzec je i zidentyfikować, kiedy brak mu tak wyraźnie zarysowanego kontekstu. Nie jest zatem pewne, czy usuwając z procesu wychowania przemoc i tyranię, pozbędziemy się zarazem okrucieństwa. Innymi słowy, chcąc przeciwstawić się okrucieństwu, ryzykujemy, że zająwszy się w tym celu bardziej transparentnymi formami agresji - maltretowaniem, opresją czy manipulacją, samo okrucieństwo pozostawiamy nierozpoznane (i możliwe, że nienaruszone),

${ }^{1}$ Zob. Encyklopedia pedagogiczna XXI wieku, t. I, red. T. Pilch, Warszawa 2003, s. 39-47; J. Danielewska, Agresja u dzieci - szkoła porozumienia, Warszawa 2002; B. Śliwerski, Pseudowychowanie, [w:] B. Śliwerski, Pedagogika ogólna. Podstawowe prawidtowości, Kraków 2012, s. $313-$ 334; D. Zając, Obszary przemocy w wychowaniu, [w:] E. Kubiak-Szymborska, D. Zając, Podstawowe problemy teorii wychowania. Konteksty wspótczesnych przemian, Bydgoszcz 2006, s. 243-259.

${ }^{2}$ Cyt. za: E. Jarosz, Przemoc wobec dzieci. Reakcje środowisk szkolnych, Katowice 1998, s. 58.

${ }^{3}$ A.S. Reber, E.S. Reber, Stownik psychologii, Warszawa 2005, s. 30; zob. E. Fromm, Anatomia ludzkiej destrukcyjności, przekł. J. Karłowski, Poznań 2005, s. 5-6. 
bądź że podejrzanym uczynimy każdy rodzaj przymusu, włącznie z perswazją, widząc w nich nośnik agresji przyjmującej postać zamaskowanego okrucieństwa. Jednak i w tym wypadku pominiemy to trudne do uchwycenia zjawisko. Mało tego, starając się mu przeciwstawić i przeciwdziałać, być może z góry skazani jesteśmy na porażkę, bowiem, jak stwierdza nie bez smutku Judith N. Shklar we wstępie do książki inspirowanej myślą Michela de Montaigne'a Zwyczajne przywary, „(...) nie potrafimy żyć ani z nim, ani bez niego. I co więcej - dodaje - nic tak nie obnaża naszej własnej irracjonalności jak okrucieństwo"4.

Teza Shklar niepokoi. Rozważając jej konsekwencje na gruncie deontologii pedagogicznej, możemy dojść do wniosku, że przed wychowaniem stoi nierozwiązywalny problem, który podważa humanistyczne podstawy współczesnej edukacji ${ }^{5}$. Dlatego, mając na uwadze wymiar moralny wychowania, należy przejrzeć zjawisko ludzkiego okrucieństwa.

\section{Fizyczne i moralne okrucieństwo według J.N. Shklar}

Judith N. Shklar punktem wyjścia swoich dociekań dotyczących okrucieństwa czyni rozważania Michela de Montaigne'a. Zdaniem filozofki, renesansowy humanista jako pierwszy ze znanych nam myślicieli znaczących dla intelektualnych tradycji Zachodu uznał je za podstawowe moralne zagrożenie: „Najokrutniej - wyznał w Próbach - wśród innych przywar nienawidzę okrucieństwa, i z natury, i z zastanowienia, jako ostatecznego ze wszystkich błędów (...)"6. Przed nim zjawisko to, zauważa Shklar, zarówno jako centralne zagadnienie etyki, jak i ważny problem moralny nie absorbowało uwagi ani filozofów, ani teologów, a przynajmniej tak wynika ze znanych i dostępnych nam źródeł oraz analiz badaczki. Znaczenie Montaigne'a dla podejmowanego tu tematu wykracza poza wyróżnienie tego rodzaju zagrożenia moralnego pośród innych "zwyczajnych przywar” - zdrady, niewierności, czy tyranii, określonych przez szesnastowiecznego myśliciela

${ }^{4}$ J.N. Shklar, Zwyczajne przywary, przekł. M. Król, Kraków - Warszawa 1997, s. 11. Książka Shklar, opublikowana w 1984 roku (org. Tytuł: Ordinary Vices), traktując o moralnym i politycznym znaczeniu okrucieństwa, hipokryzji, snobizmu, zdrady i mizantropii, za punkt wyjścia przyjmuje wyliczenie autora Prób, wydanych niemal dokładnie czterysta lat wcześniej, oraz jego szkice poświęcone owym fenomenom moralnym.

${ }_{5}$ Zob. B. Śliwerski, Wychowanie jako działanie, [w:] B. Śliwerski, Pedagogika ogólna, s. 144188; S. Kunowski, Znaczenie wspótczesne wychowania, [w:] S. Kunowski, Podstawy wspótczesnej pedagogiki, Warszawa 1993, s. 19-25.

${ }^{6}$ M. de Montaigne, O okrucieństwie, [w:] M. de Montaigne, Próby, przekł. T. Boy-Żeleński, Kraków 2004, s. 325. 
tym być może zaskakującym mianem z racji, że są to - jak tłumaczy Shklar „(...) zachowania, do których wszyscy przywykliśmy, nie widzimy w nich niczego szczególnego czy nadzwyczajnego"7 . (To kolejne źródło możliwego niepokoju i dla wychowawcy, i dla badacza edukacji, podobnie jak zawarte w zakończeniu wstępu do książki wnioski filozofki dotyczące zwyczajnych przywar: „Okrucieństwo, hipokryzja, snobizm i zdrada z pewnością nigdy nie znikną" ${ }^{8}$.) Jego Próby, które w wieku siedemnastym, sto lat po ich wydaniu, trafiły na indeks ksiąg zakazanych, mimo że nie zawierają systematycznego wykładu interesującego nas zagadnienia, obfitują we fragmenty doniosłych merytorycznie dociekań, przenikliwych uwag, wartościowych dygresji, a przede wszystkim pouczających ilustracji, które mogą stanowić podstawę, o czym przekonuje nas Shklar, dla wysiłku zrozumienia problemów, jakie przynosi ze sobą zjawisko ludzkiego okrucieństwa.

Nim jednak zwrócimy się do rozważań renesansowego myśliciela, przyjrzyjmy się odczytaniu esejów Montaigne'a oraz refleksji nad okrucieństwem, jakie zawarła w Zwyczajnych przywarach współczesna teoretyczka polityki. Shklar postawienie okrucieństwa w etycznej strukturze teorii liberalnej na czele hierarchii przewinień moralnych wiąże z terrorem nowożytnych wojen religijnych. Jak podkreśla, mając na uwadze konsekwencje polityczne stosowania terroru, powstały $\mathrm{w}$ jego wyniku strach „unicestwia wolność" i sprowadza ludzi „do roli jednostek reagujących jedynie na bodźce, a więc narzuca pewien publiczny etos" ${ }^{\prime \prime}$. Strach jest nie tylko wrogiem ludzkiej wolności w tym sensie, że skutecznie odbiera poszczególnym ludziom inicjatywę i powstrzymuje ich zaangażowanie. Jego dominacja $\mathrm{w}$ połączeniu $\mathrm{z}$ długotrwałym oddziaływaniem niekorzystnie przekształca stosunki społeczne, utrwalając normy i wzorce zachowań oparte na tyranii i podporządkowaniu. Ponadto, zdaniem Shklar, to właśnie „Strach powoduje, że oprawcy stają się okrutni i strach też zwiększa cierpienia ofiar"10. Według filozofki, stanowi on motywację sprawcy okrucieństwa fizycznego, którym jest „(...) celowe zadawanie fizycznego bólu słabszemu" po to właśnie, „by wzbudzić w nim obawę i strach". Jak dodaje, jest ono „złem skie-

7 J.N. Shklar, Zwyczajne przywary, s. 9. Jako motto poprzedzające wstęp, Shklar zamieszcza fragment z eseju O kanibalach Montaigne'a: „Zdrada, niewierność, tyrania, okrucieństwo, słowem nasze zwyczajne przywary" (M. de Montaigne, Próby, s. 175).

8 Tamże, s. 14.

${ }^{9}$ Tamże, s. 10-11, 13. Zob. także: tamże, s. 34, 241-243. Zob. H. Arendt, Ludzkość a terror, [w:] H. Arendt, Salon berliński i inne eseje, przekł. M. Godyń, S. Szymański, Warszawa 2008, s. 245-256. W tym kontekście pouczające zdaje się również opowiadanie Franza Kafki, Kolonia karna.

${ }^{10}$ J.N. Shklar, Zwyczajne przywary, s. 34. 
rowanym przeciwko innej istocie"11, co wydaje się odnosić również do drugiego rodzaju okrucieństwa wyróżnionego przez badaczkę - okrucieństwa moralnego.

W podanej przez Shklar definicji okrucieństwa fizycznego oraz jej omówieniu zawartemu w książce, cztery kwestie zasługują na szczególną uwagę. Po pierwsze, wyróżnione przez nią okrucieństwo fizyczne bazuje na stosunku nierówności - ofiarą jest istota słabsza czy to fizycznie, społecznie, czy też gatunkowo. Nawet w przypadku resentymentu, o którym mówi Nietzsche, a za nim Scheler, a właściwie jego podstaw, odroczona w czasie zemsta słabszego musi umieć wykorzystać chwilowe przewagi wobec strony dominującej ${ }^{12}$. Po drugie, w odróżnieniu od etyk, w których norma moralna została ustanowiona $\mathrm{w}$ oparciu o autorytet (Shklar podaje przykład grzechu pychy chrześcijanina wobec Boga), a złamanie jej związane jest z jego odrzuceniem, obrazą lub okazaniem mu nieposłuszeństwa, okrucieństwo fizyczne jako zło uczynione „innej istocie” daje się osądzić bez odwoływania do wyższej instancji, jest bowiem „częścią składową naszego zwyczajnego, normalnego życia, a także codziennej praktyki publicznej"13. Innymi słowy, okrucieństwo fizyczne i jego ocena zdaniem filozofki odnoszą się bezpośrednio do osób w nie zaangażowanych. Nie wymagają, jak czynią to liczne doktryny religijne i etyczne, odwołania do czynników i kryteriów zewnętrznych, których uznane zwyczajowe pierwszeństwo mogłoby usprawiedliwić krzywdzące działanie sprawcy i zdezawuować cierpienia ofiary. Po trzecie, okrucieństwo fizyczne jest działaniem intencjonalnym z jednoznacznie przypisanym mu celem wzbudzenia obawy i strachu, a zatem, po czwarte, cierpienie fizyczne jest tutaj jedynie środkiem, a oczekiwany przez sprawcę skutek można osiągnąć w inny sposób (co Shklar w dalszych partiach swego eseju określa mianem okrucieństwa moralnego). Jeśli dodamy, że wywołanie strachu i obawy powoduje podporządkowanie ofiar sprawcom, to należy uznać, że charakterystyka podana przez Shklar w zasadzie pokrywa się z tym, co badacze zwykli często umieszczać pod kategorią przemocy, nie utożsamiając jej przy tym z okrucieństwem ${ }^{14}$. Nale-

11 Tamże, s. 19.

12 Zob. M. Scheler, Resentyment a moralność, przekł. J. Garewicz, Warszawa 1997. Na temat związku dystansu społecznego i okrucieństwa zob. J.N. Shklar, Zwyczajne przywary, s. 39-40. Za ilustrację zjawiska resentymentu, a także przenikliwe studium okrucieństwa może posłużyć należąca do klasyki powieść Honoriusza Balzaca, Kuzynka Bietka, jak również podobnie Kłębowisko żmij François Mouriaca.

13 J.N. Shklar, Zwyczajne przywary, s. 19.

14 Zob. D. Zając, Obszary przemocy w wychowaniu, s. 243-246. Zob. także: Przemoc i agresja jako zjawiska społeczne, red. M. Binczycka-Anholcer, Warszawa 2003; Różne spojrzenia na prze- 
ży zatem także postawić pytanie, jak podana przez filozofkę charakterystyka okrucieństwa fizycznego ma się do drugiego jego rodzaju, o jakim pisze $\mathrm{w}$ Zwyczajnych przywarach. Innymi słowy, zapytać o związek przemocy z okrucieństwem, który (jakkolwiek Shklar taki związek zakłada) jest problematyczny jeszcze z innego, niż wymieniony powyżej, powodu.

Zgodnie z przyjętą przez teoretyczkę liberalizmu definicją, zadawanie cierpienia fizycznego w innym niż chęć wzbudzenia strachu i obawy celu, jak chociażby ukarania czy też ratowania życia, nie powinno być identyfikowane jako okrucieństwo. Jednak takie rozróżnienie wydaje się trudne do utrzymania. Za przykład mogą posłużyć fragmenty z osiemnasto- i dziewiętnastowiecznych poradników wychowania, przytaczane przez Alice Miller za antologią Schwarze Pädagogik Kathariny Rutschky15, w których to poradnikach zalecanym przez ich autorów karom fizycznym towarzyszy intencja wyrobienia $\mathrm{w}$ dziecku posłuszeństwa, poprawy jego zachowania, czy sprostania potrzebie adaptacji do norm społecznych. Szwajcarska psychoanalityczka, korzystając $\mathrm{z}$ freudowskiej teorii przeniesienia, dowodzi jednak, że cel deklarowany w tych wypadkach jest wtórny wobec ukrytej i nieświadomej dla agresora intencji poniżenia słabszego, która często wynika z wcześniejszych przeżyć sprawcy - bycia ofiarą agresji ze strony kogoś silniejszego - $\mathrm{i}$ jest $\mathrm{w}$ istocie rekonfigurowanym powtórzeniem minionego upokorzenia, podobnie jak byłyby nimi akty samookaleczenia czy innych form jego autodestrukcji. Przyjęta przez terapeutkę perspektywa analizy przemocy dodatkowo skomplikuje definicyjne ujęcie okrucieństwa fizycznego proponowane przez Shklar, jeśli uznamy, że należy rozstrzygnąć kwestię, która czyni jeszcze bardziej kłopotliwe wskazanie właściwej teleologii okrucieństwa, a mianowicie: czy przynajmniej równorzędnymi celami nie są tu psychiczna kompensacja i samo powtórzenie, których zrealizowanie obiecuje sprawcy tworzona przez niego sytuacja? Natomiast sama Miller, komentując wybrane z antologii Rutschky przykłady, nie waha się użyć wobec nich określenia "okrucieństwo", jednak nie w znaczeniu, o którego uściślenie stara się Shklar, a raczej jako wyraz braku przyzwolenia na wszelkie formy przemocy i, szerzej, agresji dorosłych wobec dzieci.

Teoretyczka polityki prawdopodobnie nie zgodziłaby się z konsekwencjami poglądu, zgodnie z którym każdy akt przemocy jest $\mathrm{z}$ zasady okrucieństwem fizycznym, $\mathrm{w}$ istocie ma bowiem na celu, niezależnie od dekla-

moc, red. R. Szczepanik, J. Wawrzyniak, Łódź 2008; Agresja i przemoc: wspótczesne konteksty i wyzwania, red. K. Barłóg, E. Tłuczek-Tadla, Jarosław 2013.

15 Zob. A. Miller, Zniewolone dzieciństwo. Ukryte źródła tyranii, przekł. B. Przybyłowska, Poznań 1999, s. 23-119. 
rowanych intencji, wzbudzenie za pomocą fizycznego cierpienia strachu u słabszej od sprawcy ofiary. Jak zauważa,

Kara służyć może zadośćuczynieniu za zło, wychowaniu czy też publicznemu bezpieczeństwu, jeśli jednakże wykracza daleko poza te cele, określamy ją wówczas jako "okrutną i niezwykłą" i zabraniamy jej stosowania16.

Określenie „wykracza daleko poza te cele” wskazuje na pewien naddatek, ale jest nieprecyzyjne. Niemniej oznacza, że trzeba według Shklar czegoś więcej, by można było mówić nie tylko o tym, że dana kara jest przemocą, ale że jest okrucieństwem.

Prezentowany przez filozofkę pogląd na funkcję kary zdaje się korespondować $z$ pesymistycznym ujęciem natury człowieka i organizacji wspólnego życia ludzi, jaki możemy znaleźć u Freuda, dla którego szeroko rozumiana kultura jest efektem wymuszonej na członkach wspólnoty przez normy społeczne sublimacji ${ }^{17}$. Innymi słowy, jednostka jest zdeterminowana dynamiką działania właściwych jego organizmowi popędów, odpowiadających wraz z jego pragnieniami za psychiczne napięcia i ciśnienia powstałe w zderzeniu z moralnymi oczekiwaniami i ograniczeniami nałożonymi nań przez zbiorowość, a przemoc, użycie siły, choć moralnie naganna i psychicznie okaleczająca, okazuje się politycznie niezbędna do zachowania społecznego porządku, między innymi jako środek wzbudzania i utrzymywania wśród jej członków strachu przed możliwymi sankcjami za jego naruszanie. Ponieważ ów porządek w procesie wychowania zostaje - zwykle prawidłowo - zinternalizowany przez jednostkę, łącznie z poczuciem strachu przed jego naruszeniem, jest ona zdolna nie tylko do sublimacji i aprobowanego zachowania, ale również autocenzury oraz wymierzania sobie odpowiednich kar. (Podobne wnioski co do przemocowego charakteru kultury, choć z użyciem innej perspektywy badawczej, formułują teoretycy reprodukcji18. W konsekwencji oznacza to, że w obliczu regulacji prawnych

16 J.N. Shklar, Zwyczajne przywary, s. 35. Zob. także: H. Arendt, O przemocy, [w:] H. Arendt, O przemocy. Niepostuszeństwo obywatelskie, przekł. A. Łagodzka, W. Madej, Warszawa 1999, s. 5-135.

17 Zob. S. Freud, Kultura jako źródto cierpień, [w:] S. Freud, Pisma społeczne, przekł. A. Ochocki i in., Warszawa 1998, s. 165-227. Zob. także krytyczne omówienia Ericha Fromma (Kryzys psychoanalizy. Szkice o Freudzie, Marksie i psychologii społecznej, przekł. W. Brydak, Poznań 2000, s. 7-63; Zerwać okowy iluzji. Moje spotkanie z myśla Marksa i Freuda, przekł. J. Karłowski, Poznań 2000, s. 94-103, 127-183).

18 Zob. P. Bourdieu, J.-C. Passeron, Reprodukcja. Elementy teorii systemu nauczania, przekł. E. Neyman, Warszawa 2006; R. Moore, Socjologia edukacji, przekł. A. Sulak i in., [w:] Pedagogika, t. 2: Pedagogika wobec edukacji, polityki oświatowej i badań naukowych, red. B. Śliwerski, Gdańsk 2006, s. 345-366, 370-392. 
państwa, norm społecznych, wpływu otoczenia, wychowania, czy też charakteru i przebiegu interakcji podmiot ulega permanentnej przemocy. Na marginesie warto dodać, że teoretycy reprodukcji zdają się podzielać z pedagogami negatywnymi pogląd co do nasączenia relacji wychowawczych przemocą. W jednej z kluczowych książek dla tego nurtu badań czytamy, że wszelkie działanie pedagogiczne „stanowi obiektywnie symboliczną przemoc jako narzucenie przez arbitralną władzę arbitralności kulturowej”19).

Jeśli poglądy Miller na temat konstytucji jednostki i celu terapii odbiegają w wielu punktach od pierwotnych założeń twórcy psychoanalizy, to jednak zdają się podzielać charakterystyczną także dla pedagogiki słabość wobec inżynierii społecznej, dla której wychowanie jest równoznaczne z urabianiem jednostek i formowaniem społeczeństwa. Innymi słowy, nie jest wcale oczywiste, czy Miller, opowiadająca się za antypedagogicznymi teoriami Ekkefarda von Braunmühla, krytykując czarną pedagogikę i urabianie jednostek, odrzuca również pokusę kształtowania za pomocą wpływu na wychowanie społeczeństwa ${ }^{20}$.

Natomiast klasyczny liberalizm, w obrębie którego operuje Shklar, zakłada, że życie społeczne kształtuje polityka, a politykę autonomiczni obywatele. Teoria liberalna ${ }^{21}$ widzi jednostkę jako wolną i równoważną innym, skupia uwagę na dorosłych i niezależnych podmiotach, zakłada różnorodność postaw, skal wartości, światopoglądów, kompetencji, wiedzy, interesów oraz pozycji i statusów wspólistniejących w społeczeństwie, przyjmuje, że przeciwdziałanie wynikającym z pluralizmu konfliktom dopuszcza limitowane, redystrybuowane między poszczególne instytucje prawo do użycia siły i przymusu. Dlatego takie znaczenie ma dla filozofki zróżnicowanie rozumienia przemocy, której interesujące ją oddziaływanie moralne i polityczne wśród dorosłych wolnych obywateli będzie miało dla niej inny charakter i konsekwencje, niż dla Miller udział przemocy w rozwoju dziecka. W tym sensie okrucieństwo fizyczne to według teoretyczki polityki bezprawna i nie dająca się usprawiedliwić przemoc.

Można też powiedzieć, że obydwie badaczki nie tyle chcą mówić o samym okrucieństwie, co o przemocy i innych formach agresji; w przypadku Miller - o ich skutkach w wychowaniu, Shklar - w relacjach międzyludzkich i polityce. O ile dla Miller każde użycie siły fizycznej czy psychicznej zdaje

${ }^{19}$ P. Bourdieu, J.-C. Passeron, Reprodukcja, s. 75.

20 Ten utopijny wymiar antypedagogiki odsłania inny jej przedstawiciel, Herbert von Schoenebeck (zob. Nowa relacja, [w:] H. von Schoenebeck, Antypedagogika. Być i wspierać zamiast wychowywać, Warszawa 1994, s. 80-85).

21 Zob. J. Gray, Liberalizm, przekł. R. Dziubecka, Kraków 1994; W. Kimlicka, Wspótczesna filozofia polityczna. Wprowadzenie, przekł. A. Pawelec, Kraków 1994, s. 62-109. 
się być nadużyciem, Shklar jedynie nieuzasadnioną przemoc uznałaby za okrucieństwo. Jednak u obu wyraźne są tendencje redukujące okrucieństwo do przemocy, podczas gdy są to dwa niezależne od siebie zjawiska występujące często łącznie. Innymi słowy, okrucieństwo w ujęciu Shklar zdaje się wymykać rozumieniu, być może ze względu na przyjęte stanowisko teorii liberalnej i obszar zainteresowań reprezentowanej dyscypliny nauk o polityce, co podsuwa myśl, by w celu weryfikacji wniosków, do jakich doszła, sięgnąć bezpośrednio do źródeł jej namysłu - esejów Montaigne'a.

Nim jednak to nastąpi, jeszcze kilka słów o drugim rodzaju okrucieństwa, jakie wyróżnia filozofka mając na myśli:

rozmyślne i stałe upokarzanie, doprowadzające do tego, że w końcu ofiara nie wierzy już nikomu, nawet samej sobie. Wcześniej czy później, choć nie jest to niezbędny składnik okrucieństwa moralnego, może doprowadzić do cierpienia fizycznego. Upokorzenie jest bolesne, ale nie powoduje uszczerbku na ciele ${ }^{22}$.

Przede wszystkim, zawarta w cytacie myśl zdaje się potwierdzać wcześniej wyprowadzone wnioski, że okrucieństwo nie daje się zredukować do przemocy, a zatem istnieje tylko jeden jego rodzaj - okrucieństwo moralne, a przemoc i cierpienie fizyczne, będąc jednym $z$ wielu środków możliwego panowania nad ofiarą, pozostają osobnym, mogącym towarzyszyć okrucieństwu zjawiskiem. Również Shklar zdaje się dostarczać na rzecz tej tezy argumentu, kiedy pisze:

Montaigne był w pełni świadom, czym jest okrucieństwo moralne i traktował je jako osobiste zagrożenie, ale nigdy nie mylił go z fizyczną brutalnością23.

Fragment omówienia przez Shklar okrucieństwa moralnego wnosi jeszcze jeden istotny element do jego rozumienia. Filozofka mówi o dezorientacji ofiary, co możemy połączyć z doświadczeniem osamotnienia ${ }^{24}$, gdyż upokorzona nie potrafi sobie, a także innym, wyjaśnić przyczyny odczuwanego cierpienia. Podniesiona przez Shklar kwestia pozwala postawić pytanie: na ile akt okrucieństwa ma charakter zamaskowany? Na ile w związku z tym daje się uchwycić i wyjaśnić? Również Shklar zauważa, że jest jakiś powód, dla którego Montaigne nie wyjaśnia wprost, na czym polega okru-

22 J.N. Shklar, Zwyczajne przywary, s. 49. W podanej przez Shklar charakterystyce określenie 'stałe' może sugerować sadyzm, jednak sama filozofka rozróżnia te dwa zjawiska (zob. tamże, s. 56).

${ }^{23}$ Tamże, s. 49. Podobnie postępuje Erich Fromm w swoim niezwykłym studium: Anatomia ludzkiej destrukcyjności dotyczącym agresji, wyróżniając okrucieństwo i destrukcyjność. Niemniej wskazuje, że te dwa zjawiska występują łącznie (zob. tamże, s. 9-20).

24 Zob. J.N. Shklar, Zwyczajne przywary, s. 21, 35. 
cieństwo, ale by je przybliżyć rozumieniu czytelnika, posługuje się opowieściami. Jak tłumaczy,

Jest być może tak, że przywary, a zwłaszcza okrucieństwo, całkowicie wymykają się racjonalizacji i tylko historyjki oraz opowieści mogą uchwycić ich sens. Nie jestem tego w zupełności pewna, tu znów podzielam przezorność i sceptycyzm Montaigne'a ${ }^{25}$.

Choć zaproponowane przez Shklar rozróżnienie na okrucieństwo fizyczne i moralne wydaje się wprowadzać w błąd, należy zachować przezorność i nie rezygnować z dalszych prób określenia zjawiska.

\section{Montaigne o okrucieństwie i zwyczajach}

W rozdziale XXXI Księgi pierwszej Prób, zatytułowanym „O kanibalach", Michel de Montaigne opisuje znane mu z relacji zwyczaje obchodzenia się z jeńcami bliżej nieokreślonego plemienia „dzikich":

Jeńców żywią długi czas, obchodzą się z nimi bardzo dobrze i nie szczędzą wygód; po czym ten, który ma jakiego w swojej mocy, zwołuje wielkie zebranie swoich bliskich. Wiąże do ramienia jeńca sznur, za pomocą którego prowadzi go w odległości kilku kroków, tak aby mu nie mógł uczynić nic złego, najmilszemu zaś z przyjaciół daje tak samo do trzymania jego drugie ramię, i obaj, w przytomności całego zebrania, zabijają go razami miecza. To uczyniwszy, pieką go i zjadają wspólnie, posyłając kąski nieobecnym przyjaciołom. I nie czynią tego, jakby ktoś mógłby myśleć, dla pożywienia się, jak niegdyś Scytowie; jeno ma to wyobrażać najwyższą zemstę. Że tak jest $\mathrm{w}$ istocie, oto przykład: ujrzawszy, że Portugalczycy, którzy sprzymierzyli się $\mathrm{z}$ ich nieprzyjaciółmi, posługują się przeciw nim innym rodzajem śmierci (jeśli ich dostali $\mathrm{w}$ niewolę), a mianowicie zakopują do pasa i strzelają do wystającego ciała gęsto z łuków, a potem wieszają, powzięli sami myśl, iż ci ludzie z drugiego świata (którzy nauczyli okoliczne ludy wielu występków przedtem nieznanych i zdawali się większymi od nich mistrzami we wszelakim złoczyństwie) nie bez kozery zażywają tego rodzaju zemsty i że musi on być jeszcze bardziej piekący niż ich własny, za czym niechali dawnego obrząaku, aby naśladować ten nowy. Nie to mnie mierzi, iż odczuwamy całą barbarzyńską ohydę tego postępowania, ale to, iż oceniając trafnie ich błędy, tak ślepi jesteśmy na własne26.

Pozostawmy nierozstrzygniętą kwestię, na ile opis sporządzony przez Montaigne'a odzwierciedla wzory zachowań, jakich moglibyśmy doświadczyć w ówczesnym świecie. Rozwiązanie tej kwestii nie jest tu konieczne.

25 Tamże, s. 14.

26 M. de Montaigne, Próby, s. 174, zob. także, s. 104-105, 108, 175, 325-328. 
Zakładając, że esej jest wyrazem poglądów autora, opowieść o obyczajach zarówno kanibali, jak i Portugalczyków możemy potraktować jako ilustrację Montaigne'a pojęcia okrucieństwa. Mimo że sam termin $\mathrm{w}$ przytoczonym fragmencie się nie pojawia, odwoławszy się do tego, co o okrucieństwie pisze, opierając się na Próbach, Shklar, możemy przyjąć, że cytowany opis nie tylko potwierdza, ale i pogłębia naszą wiedzę o poglądach renesansowego humanisty na interesujący nas temat.

Porównanie przeprowadzone przez Montaigne'a między zwyczajami członków dwóch różnych grup kulturowych pozwala nam ponownie postawić pytanie o związek przemocy i okrucieństwa. Oto w akcie zemsty kanibale przygotowują posiłek z ciała jeńca wojennego. Zabijają wroga, jednak sam sposób, w który tego dokonują, wydaje się wprowadzać w całość opisywanej sytuacji dodatkowy, niezależny od aktu przemocy element. Kanibalom, jak przedstawia rzecz Montaigne, nie jest bowiem obojętny rodzaj zadanej śmierci. To, co do niej prowadzi, zdaje się wzbudzać strach jeńca i pogłębiać $\mathrm{w}$ ich mniemaniu jego cierpienie. Co równie istotne, zemsta nie kończy się wraz z jego śmiercią. Znaczenia nabiera to, co dzieje się wokół samego aktu przemocy, zarówno przed, jak i po śmierci jeńca, a co jedynie akcydentalnie jest z nim związane - zgodnie z narracją Montaigne'a kanibale decydują się zmienić rytuał i naśladować Portugalczyków, by innymi środkami i w pełniejszy sposób zrealizować zamysł zemsty. Śmierć to za mało. Chodzi o to "coś więcej”, naddatek, o którym Montaigne pisze w innym eseju: „Co do mnie, nawet w sprawiedliwości wszystko, co przekracza zwykłą śmierć, zda mi się okrucieństwem (...)"27.

Gdyby nie decyzja o zmianie rytuału, element ów oraz namiętność z nim związana pozostałyby zamaskowane pod pozorem przejętego od poprzednich pokoleń zwyczaju, który członkowie plemienia powtarzają nie tyle, jak się domyślamy, ze względu na osobiste pragnienie okrucieństwa, ale szacunek do tradycji. Owa pogłębiająca cierpienie nadwyżka, którą demaskuje w swej narracji Montaigne, zdaje się wymykać dyskusji z racji że w centrum zdarzenia lokuje się akt przemocy - zabójstwo i śmierć jeńca, a sam sposób odebrania mu życia pozostaje poza wyborem i usprawiedliwiony jest przejętym zwyczajem. A zatem, co najwyżej o nim, a nie o ludziach go kultywujących, możemy powiedzieć, że dopuszcza okrucieństwo, co jednocześnie zdejmuje za nią odpowiedzialność z realizujących wzór członków plemienia. Nietrudno wytłumaczyć, dlaczego zamordowanie jeńca jest przemocą, natomiast dowodzenie, że przygotowanie i zjedzenie ciała ofiary należy uznać za okrutne, nie jest już tak oczywiste. Na pytanie, dlaczego chcieliby-

${ }_{27}$ Tamże, s. 326. 
śmy innego rodzaju śmierci dla jeńca, moglibyśmy odpowiedzieć jedynie, że ten jest według nas okrutny, ale zapytani, dlaczego inny uważamy za mniej okrutny, prawdopodobnie byśmy zamilkli. Z pewnością okrucieństwo łatwiej odczuć, niż o nim dyskutować czy go dowodzić. Wydaje się, że na tym polega jego atrakcyjność jako narzędzia agresji.

W opisie zwyczaju plemienia kanibali dokonanym przez Montaigne'a umiemy dostrzec ową nadwyżkę być może nie tylko dzięki autorowi Prób, ale także dlatego, że wyznawcy barbarzyńskiego rytuału nie wstydzą się okrucieństwa i sami starają się je eksponować. Inaczej rzecz ma się w innym przypadku, o którym opowiada renesansowy humanista:

Św. Hilary, biskup z Poitiers, ów słynny nieprzyjaciel herezji Ariuszowej, będąc w Syrii, otrzymał wiadomość, że Abrę, jego jedyną córkę, którą zostawił w kraju wraz z matką, żądają w małżeństwo najmożniejsi panowie w okolicy, jako dziewicę pięknie odchowaną, nadobną, bogatą i w kwiecie wieku. Odpisał jej (jak to czytamy), aby odwróciła serce od wszystkich tych rozkoszy i korzyści, że w czasie swej podróży znalazł jej stadło o wiele godniejsze i wspanialsze, i oblubieńca o wiele potężniejszego i wspanialszego, który jej daruje pod dostatkiem sukien i klejnotów nieoszacowanej ceny. Zamiarem jego było wypłoszyć jej chęć i wzwyczajenie do uciech świata i całkowicie oddać ją Bogu, ale że do tego celu najkrótszym i najpewniejszym środkiem zdała mu się śmierć, nie przestaje modłami, prośbami i ofiarami dopraszać się u Boga, aby ją zabrał z tego świata i powołał do siebie. Tak się i stało: wkrótce po jego powrocie zmarła, z czego objawił osobliwą radość. (...) Żona św. Hilarego, gdy jej objawił, jako śmierć córki stała się z jego wolą i zamiarem, i pouczył, o ile stała się szczęśliwszą, opuściwszy ten świat, niż gdyby na nim pozostała, popadła w takie żądanie wiekuistej i niebieskiej szczęśliwości, iż błagała z wielką usilnością męża, aby toż samo uczynił i dla niej. I gdy Bóg, powolny ich wspólnym prośbom, powołał ją wkrótce do siebie, śmierć tę przyjęli oboje z osobliwym wprost ukontentowaniem ${ }^{28}$.

Wysoce wątpliwa wydaje się myśl, że ojciec modlący się o śmierć córki, a następnie poczytujący swe wstawiennictwo do Boga za chwalebną zasługę, rzeczywiście przyczynił się tym do jej rozstania z życiem. A jednak historia opowiedziana przez Montaigne'a niepokoi. Zaskakuje nas reakcja żony św. Hilarego, której nie tylko śmierć córki, ale i postawa, jaką zajął wobec zdarzeń biskup, powinny przynieść cierpienie, frustrację i gniew, tymczasem ból z powodu straty zbliża ją do męża i jego strategii działania. Ton opowieści Montaigne'a wydaje się być ironiczny, jednak świadomość, że wiara w Boga, religijne oddanie oraz charakterystyczny dla średniowiecza stosunek do ziemskiego życia mogą tłumaczyć autentyczną gorliwość rodziców, pomaga zrozumieć uzyskane przez żonę św. Hilarego ukojenie. Czy

${ }^{28}$ Tamże, s. 180. 
matka Abry może mieć pretensje do męża, że ten pragnął najwyższego w świetle wiary dobra dla ich córki - „wiekuistej i niebieskiej szczęśliwości"? Prośba skierowana przez nią do św. Hilarego zdaje się potwierdzać, iż wierzyła, że mąż rzeczywiście uzyskał wstawiennictwo u Boga i może jeszcze raz je uzyskać również dla niej. $Z$ racji panujących ówcześnie poglądów nie jest w stanie zdemaskować okrucieństwa męża - co nie znaczy, że go nie odczuwa - istnieje bowiem wysokie prawdopodobieństwo, że próbując go o nie oskarżyć, naraziłaby się na śmieszność i brak zrozumienia ze strony wspólnoty wiernych. Być może nie ma go również dla samej siebie. Stąd upokorzona, w poczuciu osamotnienia, nie mogąc się przeciwstawić zamaskowanemu okrucieństwu (zamaskowanemu prawdopodobnie także dla biskupa), możliwe że nie mogąc nawet zrozumieć swoich sprzecznych uczuć - bólu i rozpaczy w obliczu „wiekuistej szczęśliwości” córki - sama decyduje się poddać jego działaniu.

Zatem, na czym polega okrucieństwo? Jest to zamaskowana agresja, wskutek której ofiara czuje się osamotniona, pozostawiona sama ze swoim lękiem i cierpieniem, co w znacznym stopniu je potęguje, ulega bowiem dezorientacji co do przyczyn odczuwanego bólu i w wyniku tego dysonansu nie jest $\mathrm{w}$ stanie przekonać siebie i innych, że została skrzywdzona i należy jej się z tej racji zrozumienie oraz współczucie, innymi słowy - uznanie doznanej krzywdy. Wydaje się, że właśnie ów brak uznania dla krzywdy ofiary jest tutaj kluczowy. $Z$ racji, że okrucieństwo ma charakter zamaskowany oraz wymyka się werbalizacji, trudno owo uznanie uzyskać, co jednocześnie pomaga sprawcom pozostać poza wszelkim podejrzeniem, a często uchodzić za dobroczyńców ofiary. Podobnie w przypadku, kiedy okrucieństwo powstaje na bazie aktu przemocy lub $\mathrm{w}$ związku $\mathrm{z}$ nim, uznanie otoczenia dla cierpień osoby skrzywdzonej ogranicza się do skutków przemocy, która niejako maskuje, odwraca uwagę od pozostającego w jej cieniu, często dotkliwszego aktu okrucieństwa, a sprawcę obciąża winą jedynie za łatwiejszy do udowodnienia czyn. Zdemaskowanie okrucieństwa jest trudne, pomóc $\mathrm{w}$ tym może $\mathrm{w}$ zasadzie jedynie wyznanie sprawcy czy obnażające jego ostentacyjne obnoszenie się $\mathrm{z}$ nim.

Nie jest oczywiście tak, że w konkretnym przypadku wszystkie wcześniej wymienione warunki zostają spełnione. Jak czytaliśmy $\mathrm{w}$ jednym z podanych przez Montaigne'a przykładów, kanibale eksponowali swe okrucieństwo, co sprzyjało jego demaskacji, niemniej jednak zdajemy sobie sprawę, że rzeczowa dyskusja na temat, który rodzaj śmierci, przemocy jest mniej, a który bardziej okrutny, sprowadza się albo do twierdzeń tautologicznych - przyjmujemy coś za mniej okrutne, bo za takie właśnie to przyj- 
mujemy - albo do poczucia bezsilności. Możemy milcząco współczuć osobie skrzywdzonej, solidaryzując się z nią ze względu na odczuwane przez nią cierpienie, ale mając do czynienia $\mathrm{z}$ okrucieństwem, stajemy wobec problemów związanych z uchwyceniem, zrozumieniem bądź przekazaniem innym racji ofiary, które to działania mogłyby otworzyć jej drogę do pełnego uznania dla doznawanego bólu i wyzwolić ją z poczucia osamotnienia, które w znacznym stopniu pogłębia upokorzenie.

Rodzic słyszy: „Mamo, ja cię chyba nie kocham” - pięciolatka jest spontaniczna czy okrutna? Czy można tego dochodzić bez ryzyka okazania złej wiary? Czy może się zwierzyć ze swego poczucia osamotnienia dopiero co zaręczonej, pewnej szczęścia przyjaciółce ta, która z racji planowanych zmian utraci w jakiś sposób ważną część siebie? Co czuje uczeń, który skarżąc się opiekunom na ustawiczną przemoc ze strony jednego ze szkolnych kolegów, napotyka na wyrzut, że nie umie się bronić? Albo ten, który stał się przedmiotem krępującej anegdoty użyczanej przez rodziców znajomym podczas towarzyskich wizyt, wyrażającym $\mathrm{w}$ ten sposób przywiązanie do swej pociechy? Są dzieci, które do zabaw wybiera się zawsze ostatnie.

W popularnej amerykańskiej produkcji kina akcji zarówno pozytywny, jak i negatywny bohater stosuje przemoc, co nie przeszkadza widzom przychylniej odbierać jednego z nich. Co ich zatem różni? Skala destrukcji, motywacje, czy może i to, że jeden z nich pokazany jest jako okrutny? Podobnie dużą widownię gromadzą programy rozrywkowe, w których prezentujące się dopiero co zaistniałe na scenie osoby dobrowolnie poddają się nieskrępowanej, pewnej siebie krytyce przeprowadzanej publicznie przez grupe celebrytów.

Według Montaigne’a, a za nim Shklar, okrucieństwo należy do „zwyczajnych przywar" budujących naszą codzienność. A zatem, jest to szereg drobnych pchnięć i ukłuć, często umykających naszej uwadze, obok wielkiej skali tworzącej „splot kłamstwa, zdrady, złości i okrucieństwa”, którego przykłady podaje Iwan Karamazow w rozmowie ze swoim bratem Aleksym $^{29}$. Bohater Dostojewskiego zdaje się być jednocześnie egzemplifikacją twierdzenia filozofki, że stawianie okrucieństwa na pierwszym miejscu czyni nas podatnymi na mizantropię, a tej towarzyszyć może skłonność do gloryfikacji ofiar ${ }^{30}$.

${ }_{29}$ F. Dostojewski, Bracia Karamazow. Powieść w czterech częściach z epilogiem, przekł. A. Wat, [w:] F. Dostojewski, Dzieła wybrane, t. 6, cz. 1, Warszawa 1959, s. 282-293.

${ }^{30}$ Zob. J.N. Shklar, Zwyczajne przywary, s. 23-26. 


\section{Okrucieństwo i wychowanie według Montaigne’a}

Historia dotycząca rytuału kanibali uwidacznia interesujące przeświadczenie, które podziela być może sam autor Prób: nasza wrażliwość na okrucieństwo jest trwałą dyspozycją przekraczającą granice kulturowe. Oto bowiem zwróciwszy uwagę na postępowanie Portugalczyków i doceniwszy jego barbarzyństwo, członkowie egzotycznego plemienia decydują się zmienić charakterystyczny dla siebie zwyczaj. Można uznać, że ich gest świadczy jedynie o wspólnej ludziom gradacji fizycznego bólu, jednak Montaigne wskazuje na reakcję Europejczyków, odczuwających „całą barbarzyńską ohydę" kultywowania kanibalizmu. Wprawdzie wrażliwość na okrucieństwo innych nie idzie tu $\mathrm{w}$ parze $\mathrm{z}$ umiejętnością dystansowania się wobec rodzimych praktyk kulturowych, dostrzegania własnych "błędów”, ale nie oznacza też jej zupełnego zaniku. Montaigne wyznaje, że także u niego nie uległa znieczuleniu wraz z liczbą napotkanych przypadków czy biegiem lat:

Żyję w czasach obfitujących w niewiarygodne wprost przykłady okrucieństwa, a to przez rozpasanie wojen domowych. W całych starożytnych dziejach nie znajduję nic straszliwszego nad to, czego doświadczamy każdego dnia: ale w niczym mnie to nie oswoiło ${ }^{31}$.

Mimo że kwestia powszechnej ludzkiej wrażliwości na okrucieństwo pozostaje nierozstrzygnięta przez autora Prób, sam trop wydaje się godny uwagi i przemyślenia.

Pod innym jeszcze względem Montaigne zdaje się rozważać zagadnienie uniwersalnego charakteru okrucieństwa - skłonność do niego stanowi zdaniem renesansowego humanisty, choć w tej kwestii nie jest konsekwentny, składnik natury ludzkiej. W eseju O okrucieństwie zauważa:

Natura (tak się obawiam) sama zaszczepiła człowiekowi jakowyś instynkt nieludzkości. Nikt nie znajduje uciechy w tym, aby patrzeć, jak bydlątka igrają i kuglują z sobą: nikomu zasię nie sprzykrzy się pozierać, jak się rozszarpują i targają ${ }^{32}$.

(Choć trudno zgodzić się z twierdzeniem, że „nikt nie znajduje uciechy w tym, aby patrzeć, jak bydlątka igrają i kuglują", to jednak zdajemy sobie sprawę, że nieproporcjonalnie większą liczbę publiczności gromadzą sceny przemocy i okrucieństwa).

31 M. de Montaigne, Próby, s. 327. Zob. P. Sloterdijk, A. Finkielkraut, Stadion i arena, przekł. M. Księżniak, [w:] Kultura demokracji, red. K. Liszka, R. Włodarczyk, Wrocław 2009, s. 135-141.

${ }^{32}$ M. de Montaigne, Próby, s. 328. 
W podobnym tonie wypowiada się $\mathrm{w}$ rozdziale pierwszym trzeciej księgi Prób:

Istota nasza jest jednym zlepkiem niezdrowych przymiotów (...) na widok bowiem cierpień drugiego, w samej pełni współczucia, czujemy we wnętrzu jakoweś słodkokwaśne ukłucie złośliwej rozkoszy; dzieci nawet je odczuwają (... $)^{33}$.

To jednak, jak ów „instynkt nieludzkości” będzie się rozwijał lub w jaki sposób zostanie stłumiony, zależy od wpływu środowiska wychowawczego. Montaigne dostrzega ambiwalencję oddziaływań rodziców i wychowawców wobec naturalnych, jak wynikałoby z wcześniejszych cytowań, skłonności dzieci - tendencjom humanistycznym, zauważa, towarzyszy przyzwolenie na pielęgnację ludzkich przywar, w tym okrucieństwa:

Uważam, że największe przywary czepiają się nas w dzieciństwie (...). Matki śmieją się, patrząc, jak dziecko skręca szyję kurczęciu lub dla igraszki znęca się nad psem i kotem; niejeden ojciec jest tak głupi, że uważa za objawy rycerskiego serca, kiedy syn jego łaje zelżywie chłopa albo pachołka niemogącego się bronić; a za bystrość dowcipu, kiedy widzi, jak wystrychnie na dudka kolegę przez jakowąś chytrość i oszukaństwo. A wszakże to są szczere nasiona i korzenie okrucieństwa, tyranii i zdrady: kiełkują tam i wyrastają później dzielnie i wzmagają się w siłę pod dłonią przyzwyczajenia. Zły to sposób wychowania usprawiedliwiać te szpetne skłonności młodym wiekiem i błahością przedmiotu ${ }^{34}$.

Oczywiście, zdaniem Montaigne’a należy przeciwdziałać utrwalaniu szkodliwych nawyków przez wdrażanie i przyzwyczajanie do wartościowych zachowań:

Trzeba pilnie nauczyć dzieci - zaleca - aby nienawidziły zła dla jego własnej ohydy, i pokazać im naturalną jego szpetotę, iżby go unikały nie tylko w uczynku, ale zwłaszcza w sercu; aby sama myśl występku była już dla nich wstrętna, bez wzglę$\mathrm{du}$, jaką maskę na się przybierze ${ }^{35}$.

Wpojone $\mathrm{w}$ procesie wychowania korzystne nawyki są tym, co może powstrzymywać ludzi przed uciekaniem się do okrucieństwa. Montaigne jest jednym z tych myślicieli, którzy dużą wagę przywiązują do praktyk kulturowych, w których osadzone jest ludzkie działanie i myślenie ${ }^{36}$. Stąd

33 Tamże, s. 597.

34 Tamże, s. 103, zob. także: s. 143, 297, 541-542.

35 Tamże, s. 103.

36 Znamienną uwagę na temat relacji między działaniem a myśleniem umieszcza Montaigne w eseju: $O$ zwyczaju i o tym, aby niełatwo odmieniać istniejace prawo: „I czyż prosty jego rozkaz [obyczaju - R.W.] nie wszczepia w najgrubsze pospólstwo tego, czego cała filozofia nie jest zdolna ugruntować w najmędrszych głowach?" (tamże, s. 107). 
w przyzwyczajeniach dostrzega on szansę na skuteczny środek kontroli społecznej:

Prawa sumienia - twierdzi - o których powiadamy, iż pochodzą z natury, rodzą się ze zwyczaju. (...) główna potęga zwyczaju jest w tym, iż chwyta nas on i niewoli w taki sposób, że nieomal nie zostawia żadnej możności wydobycia się z jego szponów i wejścia w siebie dla zastanowienia się i wyrozumowania jego nakazów ${ }^{37}$.

Przytoczone fragmenty z esejów Montaigne'a uwidaczniają inny jeszcze aspekt obecności wychowania i przyzwyczajeń w naszym życiu, który należy uznać za istotny dla podjętej problematyki. Być może dlatego właśnie, że, jak twierdzi renesansowy humanista, „(...) przyzwyczajenie przysłania nam prawdziwy obraz rzeczy"38, okrucieństwo daje się zamaskować. Innymi słowy, w takim wypadku obyczaj, podobnie jak wydane przez wyższą instancję prawo, nie tylko odwraca naszą uwagę od roli sprawcy upokorzenia, jego inicjatywy i dokonanego nadużycia, ale również zdejmuje z niego odpowiedzialność za skutki podjętych działań oraz uzasadnia i czyni czymś zwyczajnym, wręcz oczekiwanym, samą ich obecność. Zatem, remedium zaproponowane przez Montaigne'a, mające zapobiegać rozwojowi szpetnych skłonności dzięki wychowaniu kształtującemu uczynki i serca, utrwalającemu wartościowe nawyki ludzi i odpowiadające im prawa sumienia zgodne $\mathrm{z}$ panującym $\mathrm{w}$ określonej zbiorowości zwyczajem, sprzyja $\mathrm{w}$ pewien sposób zagrożeniu moralnemu, któremu chce przeciwdziałać. Przyzwyczajenie samo w sobie nie musi zawierać i konserwować okrucieństwa, ale niewoląc nas i przysłaniając sobą "prawdziwy obraz rzeczy", sprzyja jego skrytej obecności $\mathrm{w}$ naszym życiu. $\mathrm{W}$ tym sensie rację może mieć Shklar, kiedy twierdzi, że „Okrucieństwo, hipokryzja, snobizm i zdrada z pewnością nigdy nie znikną", a biorąc pod uwagę obecny stan praktyk kulturowych, "do których wszyscy przywykliśmy", a które wbrew nadziejom Montaigne'a nadal pielęgnują nasze szpetne skłonności - także okrucieństwo, może mieć rację również i w tym, że „nie potrafimy żyć ani z nim, ani bez niego". To są, jak było powiedziane, istotne źródła niepokoju zarówno dla wychowawców, jak również badaczy edukacji.

Jest jednak jeszcze inna lekcja, którą daje nam Montaigne: „Ohyda okrucieństwa - zauważa - bardziej mnie zaprawia do łagodności, niżby to jaki-

\footnotetext{
37 Tamże.

38 Tamże, s. 108, zob. także: s. 102-113; J.N. Shklar, Zwyczajne przywary, s. 38-39.
} 
kolwiek rzecznik łagodności zdołał osiągnąć"39. Być może praktykując łagodność i krytyczne myślenie, których świadectwem jest nie tylko cytowany fragment, ale w pewnym sensie całość Prób, jesteśmy w stanie unikać zadawania, jak również doznawania bólu biorącego się z okrucieństwa, unikać strachu, dezorientacji i osamotnienia, a także demaskując ową nadwyżkę i szukając uznania dla racji ofiar, zmniejszać ich cierpienia. Idąc tym tropem, należy rozważyć, czy obok kształtowania wartościowych przyzwyczajeń, obowiązek wychowania do łagodności i krytycznego myślenia, mających przeciwdziałać pojawianiu się okrucieństwa w edukacji i życiu codziennym, nie mógłby stanowić istotnego wkładu deontologii pedagogicznej do pedeutologii oraz etyki pedagogicznej i zawodowej.

Na koniec jeszcze jeden przykład podwójnego okrucieństwa. Znany jako Hiob wyszydzany przez żonę obraz Georgesa de La Toura przedstawia kobietę pochyloną nad udręczoną postacią starca. Siedzący na kamiennym bloku prawie nagi Hiob przechyla głowę, by dojrzeć w ciemności jej oświetlaną przez świecę twarz. Starzec słucha. Przekazana w biblijnym tekście wypowiedź żony nie daje się jednoznacznie interpretować, niemniej można uznać, że w odróżnieniu od mających niebawem przybyć przyjaciół męża, kobieta nie obwinia go za spadłe na nią, jego, ich bliskich i wspólny dom nazbyt liczne nieszczęścia. Zdaniem Bildada, jak również pozostałych towarzyszy przeżywającego udrękę Hioba, jego nędza i cierpienia muszą być zasłużoną karą za tajone lub zapomniane grzechy. Skądinąd wiemy, że tak nie jest. Bóg doświadcza Hioba, jednak nie za jego winy. Przeciwnie, w początkowych scenach księgi jesteśmy świadkami, i tylko my, dyskusji Stwórcy z szatanem, w której ten pierwszy przedstawia swemu przeciwnikowi męża z Us jako nieskazitelnie prawego. Przyjaciele Hioba tłumaczą zaistniałą sytuację inaczej. Cała ich okrutna tyrada zdaje się streszczać w wypowiedzi Elifaza z Themanu: „Czy istnieje człowiek sprawiedliwy wobec Boga, wobec stwórcy swojego czysty mąż?” (Ks. Hioba 4,12). Nie mają złych intencji, tak im podpowiada ich wiara. Co może powiedzieć Hiob niedowierzającym mu i nierozumiejącym go przyjaciołom, kiedy wszelkie tłumaczenia zawodzą? Ironiczne: „Wy zaprawdę, wyście jedni ludźmi, a wraz z wami zamrze mądrość!” (Ks. Hioba 12,2) zdaje się być jednocześnie wyrazem rezygnacji, jak i osamotnienia. Czy Hiob wierzy sam sobie, skoro żąda wyjaśnień bezpośrednio od Stwórcy?

Płótno de La Toura zatrzymuje naszą uwagę na innym momencie losów wiernego sługi. Trzecioplanowa w biblijnej opowieści postać kobieca znajduje się $\mathrm{w}$ centrum poetyki barokowego artysty. Gdybyśmy nie znali treści

${ }^{39}$ M. de Montaigne, Próby, s. 697. 
tekstu, moglibyśmy przyjąć, że jej twarz wyraża łagodność i zrozumienie, a ona sama jest kimś, kogo Alice Miller nazywa „wiedzącym świadkiem”, to znaczy kimś, kto z racji swych doświadczeń i przeżyć jest w stanie uznać racje ofiary okrucieństwa i empatycznie wesprzeć ją, by nie czuła się osamotniona $\mathrm{w}$ cierpieniu ${ }^{40}$. Ale to jedynie przypuszczenie. Tym bardziej problematyczne, że, jak czytamy w talmudycznym traktacie Bawa Batra, "Hiob nie istniał i nie został stworzony. On był tylko przypowieścią" (15a).

\section{BIBLIOGRAFIA}

Agresja i przemoc: wspótczesne konteksty i wyzwania, red. K. Barłóg, E. Tłuczek-Tadla, Jarosław 2013.

Arendt H., O przemocy. Niepostuszeństwo obywatelskie, przekł. A. Łagodzka, W. Madej, Warszawa 1999.

Arendt H., Ludzkość a terror, [w:] H. Arendt, Salon berliński i inne eseje, przekł. M. Godyń, S. Szymański, Warszawa 2008.

Bourdieu P., Passeron J.-C., Reprodukcja. Elementy teorii systemu nauczania, przekł. E. Neyman, Warszawa 2006.

Danielewska J., Agresja u dzieci - szkoła porozumienia, Warszawa 2002.

Dostojewski F., Bracia Karamazow. Powieść w czterech częściach z epilogiem, przekł. A. Wat, [w:] F. Dostojewski, Dzieła wybrane, t. 6, cz. 1, Warszawa 1959.

Encyklopedia pedagogiczna XXI wieku, t. I, red. T. Pilch, Warszawa 2003.

Freud S., Kultura jako źródło cierpień, [w:] S. Freud, Pisma społeczne, przekł. A. Ochocki i in., Warszawa 1998.

Fromm E., Kryzys psychoanalizy. Szkice o Freudzie, Marksie i psychologii społecznej, przekł. W. Brydak, Poznań 2000.

Fromm E., Zerwać okowy iluzji. Moje spotkanie z myślą Marksa i Freuda, przekł. J. Karłowski, Poznań 2000.

Fromm E., Anatomia ludzkiej destrukcyjności, przekł. J. Karłowski, Poznań 2005.

Gray J., Liberalizm, przekł. R. Dziubecka, Kraków 1994.

Jarosz E., Przemoc wobec dzieci. Reakcje środowisk szkolnych, Katowice 1998.

Kimlicka W., Wspótczesna filozofia polityczna. Wprowadzenie, przekł. A. Pawelec, Kraków 1994.

Kunowski S., Znaczenie wspótczesne wychowania, [w:] S. Kunowski, Podstawy wspótczesnej pedagogiki, Warszawa 1993.

Miller A., Zniewolone dziecinstwo. Ukryte źródła tyranii, przekł. B. Przybyłowska, Poznań 1999.

Miller A., Gdy runą mury milczenia, przekł. J. Hockuba, Poznań 2006.

Montaigne M. de, O okrucieństwie, [w:] M. de Montaigne, Próby, przekł. T. Boy-Żeleński, Kraków 2004.

Moore R., Socjologia edukacji, przekł. A. Sulak i in., [w:] Pedagogika, t. 2: Pedagogika wobec edukacji, polityki oświatowej i badań naukowych, red. B. Śliwerski, Gdańsk 2006.

Przemoc i agresja jako zjawiska społeczne, red. M. Binczycka-Anholcer, Warszawa 2003.

40 Zob. A. Miller, Gdy runa mury milczenia, przekł. J. Hockuba, Poznań 2006, s. 16-17, 26, 58. 
Reber A.S., Reber E.S., Stownik psychologii, Warszawa 2005.

Różne spojrzenia na przemoc, red. R. Szczepanik, J. Wawrzyniak, Łódź 2008.

Scheler M., Resentyment a moralność, przekł. J. Garewicz, Warszawa 1997.

Schoenebeck H. von, Nowa relacja, [w:] H. von Schoenebeck, Antypedagogika. Być i wspierać zamiast wychowywać, Warszawa 1994.

Shklar J.N., Zwyczajne przywary, przekł. M. Król, Kraków - Warszawa 1997.

Sloterdijk P., Finkielkraut A., Stadion i arena, przekł. M. Księżniak, [w:] Kultura demokracji, red. K. Liszka, R. Włodarczyk, Wrocław 2009.

Śliwerski B., Pseudowychowanie, [w:] B. Śliwerski, Pedagogika ogólna. Podstawowe prawidtowości, Kraków 2012.

Śliwerski B., Wychowanie jako działanie, [w:] B. Śliwerski, Pedagogika ogólna. Podstawowe prawidtowości, Kraków 2012.

Zając D., Obszary przemocy w wychowaniu, [w:] E. Kubiak-Szymborska, D. Zając, Podstawowe problemy teorii wychowania. Konteksty wspótczesnych przemian, Bydgoszcz 2006. 